Tạp chí Công nghệ Sinh học 14(1): 149-156, 2016

\title{
BIOLOGICAL CHARACTERIZATION OF FUNGAL ENDOPHYTES ISOLATED FROM AGARWOOD TREE AQUILARIA CRASSNA PIERRE EX LECOMTE
}

\author{
Hoang Kim Chi, Le Huu Cuong, Tran Thi Nhu Hang, Nguyen Dinh Luyen, Tran Thi Hong Ha, Le Mai \\ Huong
}

Institute of Natural Products Chemistry, Vietnam Academy of Science and Technology

Received: 15.5 .2015

Accepted: 30.12 .2015

\section{SUMMARY}

In recent years, a considerable number of studies on the role of microbes in agarwood production have been carried out in plants of the species Aquilaria. Based on the fact that there is a relationship between the microorganisms residing inside the plant and the agarwood formation, we isolated and characterized endophytic fungi associated with A. crassna samples collected from Southern Vietnam. Morphological identification and DNA barcoding analysis of the fungal endophytic isolates indicated that they were classified at least into three groups of diverse genera: Geotrichum, Fusarium and Colletotrichum belonging to families Dipodascaceae, Nectriaceae and Glomerellaceae, respectively. Noteworthy, Geotrichum candium strain SHTr1 isolated from a dark colored woody sample of agarwood was able to produce a fruity odor and exhibited a slight antimicrobial activity against the test bacterium Staphylococcus aureus. Another fungal isolate, Fusarium verticillioides SHTr3's, showed a moderate antimicrobial activity against a test Gram positive bacteria Bacillus subtillis and $S$. aureus with MIC values at $50 \mu \mathrm{g} . \mathrm{mL}^{-1}$. At $200 \mu \mathrm{g} . \mathrm{mL}^{-1}$, the ethyl acetate extracts of fungal isolates $F$. verticillioides $\mathrm{SHTr} 3$ and Colletotrichum truncatum $\mathrm{SHTrHc} 7$ were found to have comparable scavenging abilities on DPPH-free radicals with 53.87 and $71.82 \%$, respectively. The present results contribute to a depiction of a diverse fungal endophytic community in Vietnamese agarwood plant $A$. crassna and provide important information for further understanding of the role of endophytic fungi in agarwood formation and therapeutic applications of host plants in general.

Keywords: Aquilaria crassna, endophytic fungi, Geotrichum candium, Fusarium verticillioides, Colletotrichum truncatum

\section{INTRODUCTION}

Agarwood is the resinous and fragrant heartwood that is derived from the wounded trees of the genera Aquilaria and Gyrinops of the family Thymelaeaceae (Myrtales) (Blanchette, 2006). Rogers (2009) highlighted the most important plant species that biosynthesize agarwood, Aquilaria agollocha, A. malaccensis and A. crassna. These plants were described as large evergreens that are found in the areas ranging from India and throughout Southeast Asia. Because of its historical use in medicine, in fragrances as an aromatic oil, and also in religious ceremonies, agarwood has become one of the most valuable non-timber forest products with ranging prices in consumer countries by as much as 30,000 USD per kilogram for top quality wood (Hansen, 2000; Jayachandran et al., 2014). Because of the over-exploitation of agarwood in recent decades, the wild plants have been reduced in number and critically endangered (The IUCN Red List of Threatened Species $<$ http://www.iucnredlist.org $>$ ). To date, a total number of 19 species of Aquilaria have been listed in South East Asia region. Among them, A. crassna is the most native to Vietnam where its distribution is sparse but widespread (Naef, 2011).

Various studies have been carried out in order to find out effective ways for enhancing agarwood formation in Aquilaria and Gyrinops plants that may help to minimize the exploitation of the plants worldwide. For example, artificial wound in the trunk of grown plants and biological treatments were tested to induce the agarwood formation. Tamuli et al. (2005) stated that essential oils of the eaglewood tree A. agallocha Roxb. are products of pathogenesis with involvement of Aspergillus niger as a dominant fungi in stem. Other pathogenic fungi found in the agarwood are Fusarium sp., Penicillium sp., and Trichoderma sp. (Tamuli et al., 2005). Jayachandran 
et al. (2014) compared the essential oil contents from different categories of infected plants of $A$. malaccensis and found an apparent higher level of aromadendrene 2 in the highly infected wood $(24.76 \%)$ in comparison to the moderately infected $(1.73 \%)$ and the less infected woods (1.58\%). Interestingly, the compound was totally absent in the wood oil of healthy plants (Jayachandran et al., 2014).

Fungal endophytes, the group of special fungi which reside internally in plant tissues without causing any apparent effects, have become an interest of study due to their ability in producing novel active compounds (Strobel, Daisy, 2003; Porras-Alfaro, Bayman, 2011). The variation of fungal communities under different living conditions and host plant species, as well as host tissue types have also been observed in previous studies (Mishra et al., 2012, Lamit et al., 2014). To date, investigations in host plants belonging to Aquilaria spp. in Vietnam have been limited. The present study was undertaken to characterize endophytic fungi isolated from samples of $A$. crassna Pierre ex Lecomte in Northern Vietnam, and additionally to investigate antimicrobial and antioxidant activities, of these fungal isolates.

\section{MATERIALS AND METHODS}

\section{Isolation and culture of endophytic fungi}

Endophytic fungi were isolated from fresh materials of agarwood plant samples - Aquilaria crassna Pierre ex Lecomte, collected from Nha Trang (Khanh Hoa province) situated in Southern Vietnam. Different parts of the samples, including fruits, leaves, and woody samples, especially inner parts of the woods which appeared in dark color, were exposed by knife disinfected with $70 \%$ ethanol, and followed by a surface sterilization according to Schluz et al. (1993). Segments (0.5 cm in size) from sterilized samples were placed in Petri dishes containing Potato dextrose agar (PDA, broth of sliced potatoes 200 g. $\mathrm{L}^{-1}$, dextrose 20 g.L. $\mathrm{L}^{-1}$, agar 15 g. $\mathrm{L}^{-1}, \mathrm{pH}$ 6) and chloramphenicol $\left(50 \mu \mathrm{g} . \mathrm{mL}^{-1}\right)$ (StGermain, Summerbell, 1996), incubated at $30^{\circ} \mathrm{C}$ and monitored every day to check the growth of fungal hyphae from the segments. Fungal mycelia growing from segments were then re-cultivated, purified and transferred to fresh PDA slants and stored at $4{ }^{\circ} \mathrm{C}$.

\section{Identification of fungal endophytic isolates}

All isolates were initially grouped based on morphological characteristics like colony shape, color of the aerial hyphae, growth rate in PDA medium, and microscopic features of reproductive structures. Representative strains of each morphological group were then selected for molecular identification.

DNA extraction, amplification of fungal ribosomal DNA, sequencing and sequence analysis were carried out for the molecular identification of fungal strains. The extraction of fungal DNA was carried out according to the manufacturer's protocols (DNeasy Plant Mini kit, Qiagen). For PCR amplification, MasterCycler EP Gradient S cycler (Eppendorf, Germany) was applied, using the primers ITS1 (TCCGTAGGTGAACCTGCGG) and ITS4 (TCCTCCGCTTATTGATATGC) (White et al., 1990). The PCR was started with an initial denaturation at $95^{\circ} \mathrm{C}$ for $3 \mathrm{~min}$, followed by 30 cycles of denaturation at $95^{\circ} \mathrm{C}$ for $45 \mathrm{~s}$, annealing at $50^{\circ} \mathrm{C}$ for $35 \mathrm{~s}$, and elongation at $72^{\circ} \mathrm{C}$ for $1.5 \mathrm{~min}$, and final elongation took $10 \mathrm{~min}$ at $72^{\circ} \mathrm{C}$. The sequencing of PCR products was performed on $\mathrm{ABI}$ 3100 Avant Genetic Analyzer (Applied Biosystems, USA). The sequences were then compared with those available in GenBank via BLASTN searches (http://blast.ncbi.nlm.nih.gov/Blast.cgi) (Altschul et al., 1997). Software BioEdit v7.0.5.2 was used for sequence analyses (Hall, 1999).

Extraction of bioactive compounds from endophytic fungi for biological evaluation

Endophytic strains were cultivated at $25^{\circ} \mathrm{C}$ for 14 days in $150 \mathrm{~mL}$ of potato dextrose broth (PDB) with constant shaking (200 rpm) in an incubator shaker (IKA, Germany). The fermentation broth was extracted with an organic solvent (ethyl acetate, XL, China) in a $500-\mathrm{ml}$ Erlenmeyer flask by vigorous soaking at ambient temperature. Extractions were repeated three times and combined. The crude extracts obtained were then concentrated at reduced pressure in a rotary vacuum evaporator (EYELA, Japan) $\left(50^{\circ} \mathrm{C}\right.$ at $\left.40 \mathrm{rpm}\right)$ and subsequently dissolved in dimethyl sulphoxide (DMSO) (Sigma Aldrich, Germany) for biological assessments.

\section{Antimicrobial activity assay}

The prepared crude ethyl acetate extracts of fungal endophytes were tested against 8 microbial strains, namely Escherichia coli ATCC 25922 (Gram negative), Pseudomonas aeruginosa ATCC 25923 (Gram negative), Bacillus subtillis ATCC 
11774 (Gram positive), Staphylococcus aureus subsp. aureus ATCC 11632 (Gram positive), Aspergillus niger 439 (filamentous fungi), Fusarium oxysporum M42 (filamentous fungi), Candida albicans ATCC 7754 (yeast) and Saccharomyces cerevisiae SH 20 (yeast). A modification of the broth dilution test method (Vlietinck, 1998; Langfied et al., 2004) in sterile 96-well microplates was used to detect antimicrobial activity of selected fungal strains. Briefly, test samples with their serial diluted concentrations were added into wells that were subsequently filled with test microbial suspensions $\left(10^{6}-10^{8} \quad\right.$ cells $\left./ \mathrm{mL}\right) . \quad$ Medium containing $1 \%$ DMSO was used as a negative control, and streptomycin sulfate and nystatin were used as a positive control. The microplates were subsequently incubated for $24 \mathrm{~h}$ at $37^{\circ} \mathrm{C}$ for bacteria and $48 \mathrm{~h}$ at $25^{\circ} \mathrm{C}$ for fungi. Minimum inhibitory concentrations (MICs), the lowest concentrations of samples that inhibit the visible growth of a particular test microorganism, were then observed and recorded.
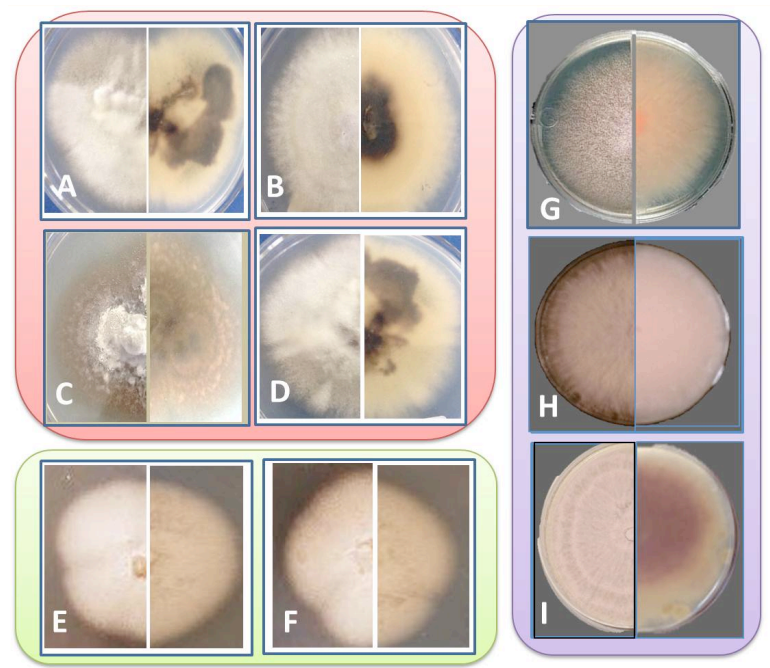

Figure 1. Grouped morphological fungal strains isolated from A. crassna samples. Group I: A (SHTr2), B (HTrHc7), C (SHTrHc8) and D (SHTrHc9). Group II: E (SHTr1) and F (SHTr4). Group III: G (SHTr3), H (SHTr5) and I (SHTr6). Each image of fungal cultivation composed of top view (left half) and bottom view (right half).

\section{RESULTS AND DISCUSSION}

\section{Isolation}

A total of 9 fungal isolates were obtained from the samples of A. crassna and named SHTr1, SHTr2, SHTr3, SHTr4, SHTr5, SHTr6, SHTrHc7, SHTrH8,

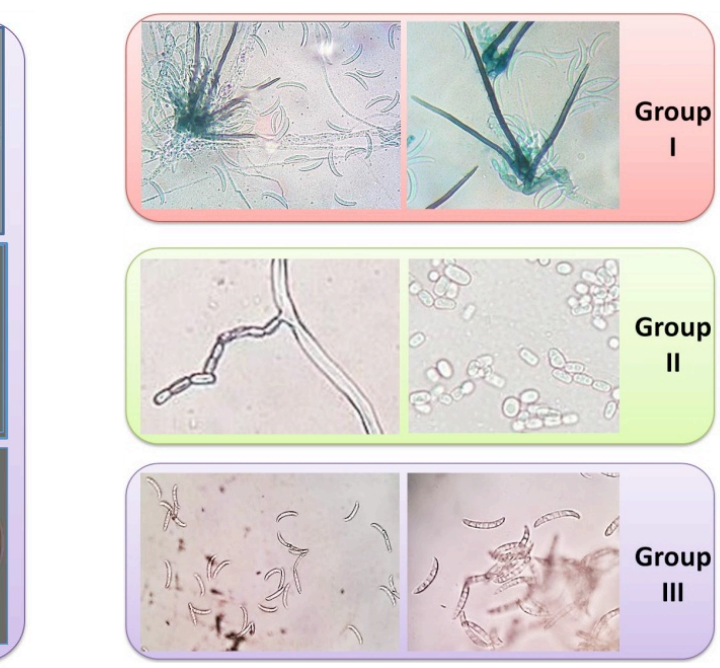

\section{Antioxidant assays}

The antioxidant potential of the fungal isolates was tested using 1,1-diphenyl-2-picrylhydrazyl (DPPH) free radical assays (Brand-Williams, 1995; Shela et al., 2003) in 96-well microtiter plates. Briefly, $10 \mu \mathrm{L}$ extract solution at serial diluted concentrations were added into a well containing 190 $\mu \mathrm{L}$ of DPPH in ethanol (Sigma Aldrich, Germany). Reactions of the extract with DPPH took place at $37^{\circ} \mathrm{C}$ for $30 \mathrm{~min}$ in the dark. The absorbance of mixtures was measured at $515 \mathrm{~nm}$ against a blank which prepared the same way using $1 \%$ DMSO instead of fungal extract). Radical scavenging activities of test samples were calculated using following formula:

$$
\mathrm{SC} \%=\left[100-\frac{\mathrm{OD}(\text { sample })-O D(\text { blank })}{O D(\text { control })} \times 100\right] \pm \sigma
$$

SC50 values of test samples were calculated by interpolation from linear regression analysis. 
mycelium. Group III is recognized by white but purplish mycelium. Macroscopic characteristics of the fungal isolates are visualized in Figure 1 . Interestingly, most fungal endophytes of the Group I were isolated from softer parts of the plant samples like fruits and leaves, while endophytic strains of the Group II were from inner parts of woody samples.

\section{Identification of fungal endophytic isolates}

Fungal strains (SHTr1, SHTr3 and SHTrHc7) were chosen as representative of each morphological group to be studied by molecular biological method. Phylogenetic analyses of these strains were carried out by ITS1-5.8S-ITS2 ribosomal gene sequencing. Table 1 provides the list of chosen endophytes and their BLAST results, showing the coverage of the sequences and sequence similarities with the most closely related organisms.

According to the results presented in Table 1, the ITS sequence of strain SHTr1 match absolutely to those of four species Galactomyces geotrichum, Galactomyces reessii, Galactomyces candidum, and Geotrichum candidum in GenBank. Based on DNA-DNA reassociation data, the genus Galactomyces consisted of Ga. reessii, Ga. citriaurantii and four closely related species of the $G e$. candidum complex (Naumova et al., 2001). Interestingly, Geotrichum candidum is straightened out to be the anamorph of Ga. geotrichum (de Hoog, Smith, 2004), then again Geotrichum candidum is the anamorph synonym of Galactomyces candidum (http://www.mycobank.org/ [MB\#182997]). As a result, it is now necessary to determine whether SHTr1 is a Ga. geotrichum (synonym of $G a$. candidum, telemorph of Ge. candidum) or a $G a$. reessii strain. Beside numerous similarities of $G a$. reessii and Ga. geotrichum, Kurtzman et al. (2011) pointed out morphological and culturing differences between the two fungal species at ascosporal sizes and also at the ability to ferment glucose, assimilate mannitol or grow on media without vitamins. Additional experimental results following the molecular biological study revealed that fungal endophyte SHTr1 is able to ferment glucose. Besides, SHTr1' ascospores had the average size of 5-13(-21) x 4-6(-10) $\mu \mathrm{m}$. In combination with descriptions of Malloch (1981), it could be concluded that SHTr1 belongs to Ga. geotrichum (anamorph Ge. candidum), a ubiquitous filamentous yeast-like fungus that has been found to be either a weak plant pathogen or occasionally associated with human pulmonary disease (de Hoog, Smith, 2004). Last but not least, these results also contributed to the fact that the use of ITS region for barcoding is not the optimal method in all cases, especially for species of filamentous yeast-like fungal genus Galactomyces (as well as their anamorphs belonging to genus Geotrichum).

Table 1. BLAST results of chosen fungal isolates of $A$. crassna.

\begin{tabular}{|c|c|c|c|c|}
\hline No. & Strain code & Query coverage & $\%$ sequence similarity & $\begin{array}{l}\text { Organism with the highest } \\
\text { sequence identity }\end{array}$ \\
\hline \multirow[t]{4}{*}{1} & SHTr1 & 100 & 100 & $\begin{array}{l}\text { Galactomyces } \quad \text { geotrichum } \\
\text { (GenBank: JQ668740.1) }\end{array}$ \\
\hline & & 100 & 100 & $\begin{array}{l}\text { Galactomyces reessii } \\
\text { (GenBank: HQ436459.1) }\end{array}$ \\
\hline & & 100 & 100 & $\begin{array}{l}\text { Galactomyces candidum } \\
\text { (GenBank: GQ376093.1) }\end{array}$ \\
\hline & & 100 & 100 & $\begin{array}{l}\text { Geotrichum candidum } \\
\text { (GenBank: KM282102.1) }\end{array}$ \\
\hline \multirow[t]{3}{*}{2} & SHTr3 & 100 & 99 & $\begin{array}{l}\text { Fusarium verticillioides } \\
\text { (GenBank: KF624791.1) }\end{array}$ \\
\hline & & 100 & 99 & $\begin{array}{l}\text { Fusarium proliferatum } \\
\text { (GenBank: KM592959.1) }\end{array}$ \\
\hline & & 100 & 99 & $\begin{array}{l}\text { Lasiodiplodia theobromae } \\
\text { (GenBank: KM508496.1) }\end{array}$ \\
\hline \multirow[t]{3}{*}{3} & SHTrHc7 & 100 & 100 & $\begin{array}{l}\text { Colletotrichum truncatum } \\
\text { (GenBank: AF451907.1) }\end{array}$ \\
\hline & & 100 & 99 & $\begin{array}{l}\text { Ascochyta rabiei (GenBank: } \\
\text { EU167600.1) }\end{array}$ \\
\hline & & 100 & 98 & $\begin{array}{l}\text { Ascochyta pisi var. pisi } \\
\text { (GenBank: EU167557.1) }\end{array}$ \\
\hline
\end{tabular}


Fungal strain SHTr3 showed high sequence similarities to Fusarium verticillioides, Fusarium proliferatum and Lasiodiplodia theobromae with the same similarity of $99 \%$ (as shown in Table 1). It is therefore necessary to consider its microscopic characteristics (see Fig. 1 - Group III). The fungus L. theobromae is the anamorph of Botryosphaeria rhodina, a common endophyte and opportunistic pathogen on more than 500 tree species in the tropics and subtropics (Denman et al., 2000). However, microscopic characteristics of typical $L$. theobromae with thick-walled and pigmented spores as previously described by Alves et al. (2008) are dissimilar to those of the strain SHTr3 (Fig. 1). Thus the strain belongs either to Fusarium verticillioides (teleomorph Gibberella moniliformis) or Fusarium proliferatum (teleomorph Gibberella intermedia). Both of the species belong to the Gibberella fujikuroi species complex (Leslie, Summerell, 2006) and are distinguished from others by their microconidial chains. $F$. verticillioides and $F$. proliferatum are morphologically very similar to one another; the only presently accepted morphological discriminator between these species is the presence of polyphialides (Nirenberg, O’Donnell, 1998). Accordingly, while conidiophores of $F$. verticillioides are monophialides, those of $F$. proliferatum are monophialides and polyphialides. Due to the fact that no polyphialide was observed in the studied cultures, we concluded that SHTr3 belongs within $F$. verticillioides species. Besides, macro-morphological characteristics of SHTr3 also match those of $F$. verticillioides described by Leslie and Summerell (2006) with initial white mycelia but may develop violet pigments with age on PDA medium. $F$. verticillioides is well known as a plant pathogen on maize and found throughout the world but no mention of an existence of the fungus on woody trees. This study is therefore the first to indicate an association of $F$. verticillioides with agarwood tree.

ITS-sequences of SHTrHc7 exhibited an obvious high similarity to Colletotrichum truncatum's rDNA sequence. Compared to the microscopic morphology of fungus $\mathrm{SHTrHc} 7$ (see Fig. 1 - Group I), the fungus appeared with curved conidia measuring 15-24 × 4.0-4.5 $\mu \mathrm{m}$, and brown setae comprising 2-6 septate. It was described that the conidia of numerous species of Ascochyta are in elongated ellipsoid or in cylindrical shapes with a length/width ratio of more than 3:1 (Snell, Dick, 1971), so it could be claim that SHTrHc7 is not an Ascochyta but a Colletotrichum species. Many Colletotrichum species with curved conidia, including $C$. truncatum (teleomorph Glomerella truncata), are known as pathogens of different herbaceous plants (Damm et al., 2009). In comparing to published data (Cannon et al., 2012), C. truncatum $\mathrm{SHTrHc} 7$ is quasi the first strain of the species isolated from an A. crassna plant.

\section{Antimicrobial activity of the extracts}

Results of the antimicrobial activity assay for three fungal isolates are described in table 2. While the extract of fungal strain SHTrHc7 showed no inhibition against test microorganisms, the crude extract of SHTr3 inhibited the growth of gram positive bacteria $B$. substilis and $S$. aureus strongly with low MIC values (50 $\mu$ g.mL $\left.{ }^{-1}\right)$. SHTr1's extract were observed to have less inhibitory activity with a MIC concentration of $200 \mu \mathrm{g} \cdot \mathrm{mL}^{-1}$ against $S$. aureus.

Table 2. Antimicrobial activities of fungal extracts.

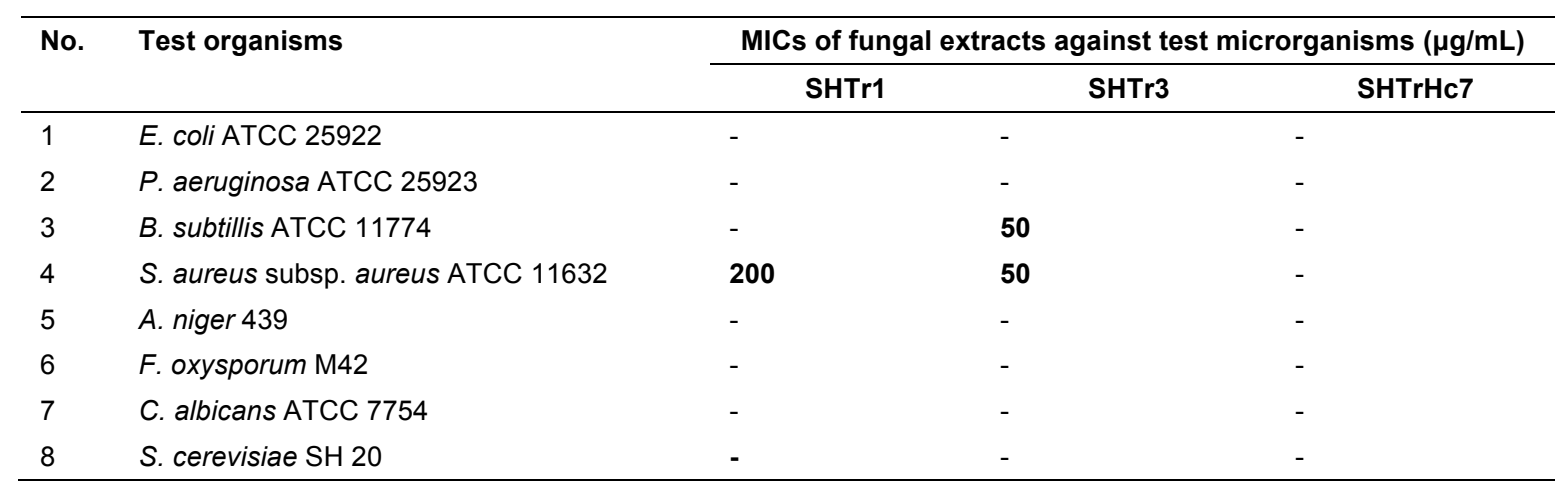

Note: Symbols: - indicates no inhibition.

Antioxidant activity of the extracts 
Antioxidant activities of the fungal extracts were tested in terms of free radical scavenging abilities and presented in forms of SC\% and SC50 values. As shown in Table 3, the ethyl acetate extract of SHTrHc7 displayed a relatively high antioxidant activity with a percentage of free radical scavenging at $71.82 \%$ and a SC50 value of $80.31 \mu \mathrm{g} \cdot \mathrm{mL}^{-1}$. A moderate scavenging capacity at $53.87 \%$ and a SC50 of $98.88 \mu \mathrm{g} . \mathrm{mL}^{-1}$ were also recorded for SHTr3's crude extract (Tab. 3). The free radical scavenging percentage of SHTr1 was measured to be $30.53 \%$, which was considered negative in the in vitro antioxidant test (see Tab. 3).

The results of both assays support data of biological activities of selected fungal endophytes in A. crassna. However, the effect of secondary metabolites of these fungal endophytic communities on chemical composition of agarwood still remains unknown.

Table 3. DPPH scavenging activities of fungal extracts.

\begin{tabular}{lllll}
\hline No. & Sample & Concentration $(\boldsymbol{\mu g} / \mathrm{mL})$ & Scavenging capacity, SC $(\%)$ & $\mathbf{S C 5 0}(\boldsymbol{\mu g} / \mathbf{m L})$ \\
\hline & Negative control & - & 0 & - \\
1 & Positive control & 50 & $92.8 \pm 1.1$ & 10.95 \\
2 & SHTr1 & 200 & $30.53 \pm 0.6$ & - \\
3 & SHTr3 & 200 & $\mathbf{5 3 . 8 7 \pm 1 . 2}$ & $\mathbf{9 8 . 8 8}$ \\
\hline
\end{tabular}

Note: Values are represented as Mean \pm SD of 3 replicates. Negative control: DPPH in EtOH. Positive control: Ascorbic acid.

\section{CONCLUSION}

In summary, three new endophytic fungi associated with agarwood plants were isolated and characterized. This is the first study to indicate their association with this plant. The ethyl acetate extracts of these fungi showed either antimicrobial activity or antioxidant activity or both. The information of these fungal species as well as knowledge of their characteristics, pharmaceutical properties would be useful for selecting suitable organisms for enhancement of agarwood production by fungal infection. To this end, futher studies should be carried out including identification of the compounds related to the antimicrobial and antioxidant activities, elucidation of chemical structures of odor from C. candidum SHTr1, improvement of bioactive compound yielded, and study of the essential oils' biosynthetic pathway in the host plant.

Acknowledgment: This work was financially supported by Ministry of Science and Technology of the Socialist Republic of Vietnam (MOST, grant of $Ð T Ð L C N .14 / 14)$. The authors are thankful to other staff members from Department of Experimental Biology (INPC, VAST) for discussing the results and for technical helps.

\section{REFERENCES}

Altschul SF, Madden TL, Schaffer AA, Zhang JH, Zhang Z, Miller W, Lipman DJ (1997) Gapped BLAST and PSIBLAST: a new generation of protein database search programs. Nucl Acids Res 25: 3389-3402.

Alves A, Crous PW, Correia A, Phillips AJL (2008) Morphological and molecular data reveal cryptic speciation in Lasiodiplodia theobromae. Fungal Diversity 28(1): 1-13.

Blanchette RA (2006) Cultivated Agarwood - Training programs and Research in Papua New Guinea Forest Pathology and Wood Microbiology Research Laboratory, Department of Plant Pathology, University of Minnesota.

Brand-Williams W, Cuvelier ME, Berset C (1995) Use of a Free Radical Method to Evaluate Antioxidant Activity. Lebensm.-Wiss. u.-Technol. 28: 25-30.

Cannon PF, Damm U, Johnston PR, Weir BS (2012) Colletotrichum-current status and future directions. Studies in Mycology 73: 181-213.

Damm U, Woudenberg JHC, Cannon PF, Crous PW (2009) Colletotrichum species with curved conidia from herbaceous hosts. Fungal Diversity 39: 45.

De Hoog GS, Smith MT (2004) Ribosomal gene phylogeny and species delimitation in Geotrichum and its teleomorphs. Stud Mycol 50: 489-515. 
Denman S, Crous PW, Taylor JE, Kang J-C, Pascoe I, Wingfield MJ (2000) An overview of the taxonomic history of Botryosphaeria, a re-evaluation of its anamorphs based on morphology and ITS rDNA phylogeny. Stud Mycol 45:129-140.

Hall TA (1999) BioEdit: a user-friendly biological sequence alignment editor and analysis program for Windows 95/98/NT. Nucl Acids Symp Ser 4: 95-98.

Hansen E (2000) The hidden history of a scented wood. Saudi Aramco World 51: 1-13.

Jayachandran K, Sekar I, Parthiban KT, Amirtham D, Suresh KK (2014) Analysis of different grades of agarwood (Aquilaria malaccensis Lamk.) oil through GCMS. Indian J. Nat. Prod. Resour 5: 44-47.

Kurtzman C, Fell JW, Boekhout T (2011) The Yeasts: A Taxonomic Study, Volume 1. 5th Edition. Elservier. New York. USA. Pp: 417-420.

Lamit LJ, Lau MK, Sthultz CM, Wooley SC, Whitham TG, Gehring CA (2014) Tree genotype and genetically based growth traits structure twig endophyte communities. American journal of botany 101(3): 467-478.

Langfied RD, Scarano FJ, Heitzman ME, Kondo M, Hammond GB, Neto CC (2004). Use of a modified microplate bioassay method to investigate antibacterial activity in the Peruvian medicinal plant Peperomia galioides. J Ethnopharmacol 94: 279-281.

Leslie JF, Summerell BA (2006) The Fusarium Laboratory Manual. Iowa, USA, Blackwell.

Malloch D (1981) Moulds: Their Isolation, Cultivation and Identification. Toronto, ON: University of Toronto Press. ISBN 978-0802024183.

Mishra A, Gond SK, Kumar A, Sharma VK, Verma SK, Kharwar RN, Sieber TN (2012) Season and tissue type affect fungal endophyte communities of the Indian medicinal plant Tinospora cordifolia more strongly than geographic location. Microbial ecology 64(2): 388-398.

Naef R. (2011) The volatile and semi-volatile constituents of agarwood, the infected heartwood of Aquilaria species: a review. FlavFrag $J$ 26: 73-87.

Naumova ES, Smith MT, Boekhout T, De Hoog GS, Naumov GI (2001) Molecular differentiation of sibling species in the Galactomyces geotrichum complex. Antonie van Leeuwenhoek 80(3-4): 263-273.
Nirenberg HI, O’Donnell K (1998) New Fusarium species and combinations within the Gibberella fujikuroi complex. Mycologia 90: 434-458.

Porras-Alfaro A, Bayman P (2011). Hidden fungi, emergent properties: endophytes and microbiomes. Ann Rev Phytopathol 49(1): 291-315.

Rogers ZS (2009) A World Checklist of Thymelaeaceae (version 1). Missouri Botanical Garden: St. Louis, MO, USA.

Schluz B, Wark U, Draeyger S, Aust HJ (1993) Endophytes from herbaceous plants and shrubs, effectiveness of surface sterilization methods. Mycol. Res. 97: 1447-1450.

Shela G, Olga MB, Elena K, Antonin L, Milan C, Nuria GM, Ratiporn H, Yong- Seo P, Soon-Teck J, Simon T (2003) Bioactive compounds and antioxidant potential in fresh and dried Jaffa sweeties, a new kind of citrus fruit. $J$. Nutri. Biolchem. 14: 154- 159

Snell WH \& Dick EA (1971) A glossary of mycology. Rev. ed.. Cambridge. Pp. 181.

St-Germain G, Summerbell R (1996) Identifying filamentous fungi: a clinical laboratory handbook. Star Publishing Company.

Strobel GA, Daisy B (2003) Bioprospecting for microbial endophytes and their natural products. Microbiol Mol Biol Rev 67: 491-502.

Sunitha VH, Nirmala D, Srinivas C (2013) Extracellular enzymatic activity of endophytic fungal strains isolated from medicinal plants. World Journal of Agricultural Sciences 9(1): 01-09.

Tamuli P, Boruah P, Nath SC (2005) Essential oil of eaglewood tree: A product of pathogenesis. J. Essent. Oil. Res. 17: 601-604.

Vlietinck AJ (1998) Screening methods for detection and evaluation of biological activities of plant preparation. Bioassay Methods in Natural Product reseach and Drug development, Kluwer acadamic publishers, USA.

White TJ, Bruns T, Lee S, Taylor JW (1990) Amplification and direct sequencing of fungal ribosomal RNA genes for phylogenetics. Pp. 315-322 In: PCR Protocols: A Guide to Methods and Applications, eds. Innis, M.A., D.H. Gelfand, J.J. Sninsky, and T.J. White. Academic Press, Inc., New York. 


\title{
NGHIÊN CÚU VÀ XÁC ĐỊNH ĐẶC ĐIỂM SINH HỌC CỦA MộT SỐ CHỦNG NẤM CộNG SINH PHÂN LẬP TỪ CẦYY TRẦM DÓ AQUILARIA CRASSNA PIERRE EX LECOMTE
}

\author{
Hoàng Kim Chi, Lê Hữu Cường, Trần Thị Như Hằng, Nguyễn Đình Luyện, Trần Thị Hồng Hà, Lê \\ Mai Hương ${ }^{\bowtie}$
}

Viện Hóa học các Hợp chất thiên nhiên, Viện Hàn lâm Khoa học và Công nghệ Việt Nam

\section{TÓM TẮT}

\begin{abstract}
Trong những năm vừa qua đã có nhiều nghiên cứu tập trung tìm hiểu về vai trò của vi sinh vật trong quá trình tạo trầm hương ở một số loài thực vật thuộc chi Trầm Aquilaria. Dựa trên giả thiết về mối liên hệ giữa vi sinh vật nội cộng sinh trong cây và sự hình thành trầm, chúng tôi đã phân lập và tìm hiểu một sô đặc điểm sinh học của các chủng nấm cộng sinh từ mẫu cây Trầm dó (A. crassna Pierre ex Lecomte) thu tại phía Nam Việt Nam. Bằng phương pháp phân tích đặc điểm hình thái kết hợp với sinh học phân tử DNA barcoding, ít nhất ba nhóm nấm cộng sinh với mẫu thực vật nghiên cứu đã được xác định, đó là các chủng nấm thuộc chi Geotrichum, Fusarium và Colletotrichum của ba họ vi nấm Dipodascaceae, Nectriaceae và Glomerellaceae. Đáng chú ý là chủng nấm Geotrichum candium SHTr1 phân lập được từ phần gỗ tối màu bên trong một mẫu thân cây có mùi hương hoa quả rất đặc trưng và biểu hiện hoạt tính kháng vi khuẩn kiểm định Staphylococcus aureus yếu. Một chủng vi nâm khác là Fusarium verticillioides SHTr3 cũng biểu hiện hoạt tính kháng hai vi khuẩn Gram dương kiểm định là Bacillus subtillis và $S$. aureus với cùng giá trị $\mathrm{MIC}$ là $50 \mu \mathrm{g} \cdot \mathrm{mL}^{-1}$. Tại nồng độ $200 \mu \mathrm{g} \cdot \mathrm{mL}^{-1}$, cặn chiết trong dung môi ethyl acetate của hai chủng nấm $F$. verticillioides $\mathrm{SHTr} 3$ và Colletotrichum truncatum SHTrHc7 biểu hiện hoạt tính chống oxy hóa trên hệ DPPH tương đối đáng kể với giá trị $\mathrm{SC}$ lần lượt là 53,87 và $71,82 \%$. Kết quả của nghiên cứu đã góp phần làm rõ thêm bức tranh đa dạng của quần xã vi sinh vật cộng sinh với cây Trầm dó $A$. crassna tại Việt Nam, cũng như cung cấp thêm dữ liệu về hoạt tính sinh học và hé lộ vai trò của các vi sinh vật này trong sự tạo trầm, qua đó đóng góp nhất định cho vấn đề bảo tồn cây gỗ quý này tại Việt Nam.
\end{abstract}

Tù khóa: Aquilaria crassna, endophytic fungi, Geotrichum candium, Fusarium verticillioides, Colletotrichum truncatum

\footnotetext{
${ }^{凶}$ Author for correspondence: E-mail: lehuong1258@gmail.com
} 